\title{
A Holistic View of Soils in Delivering Ecosystem Services in Forests: A Case Study in South Korea
}

\author{
José Luis Vicente-Vicente ${ }^{1, *} \mathbb{C}^{\text {, Sabine Fuss }}{ }^{1,2}$, Cholho Song ${ }^{3}{ }^{\circledR}$, Jongyeol Lee ${ }^{4}$, Moonil Kim ${ }^{5,6}$, \\ Woo-Kyun Lee ${ }^{3}$ and Yowhan Son ${ }^{3}$ \\ 1 Mercator Research Institute on Global Commons and Climate Change (MCC), EUREF Campus, \\ Torgauer Str. 12, 10829 Berlin, Germany; fuss@mcc-berlin.net \\ 2 Geographical Institute, Humboldt-University of Berlin, Unter den Linden 6, 10099 Berlin, Germany \\ 3 Department of Environmental Science and Ecological Engineering, Korea University, Anamro 145, \\ Seoul 02841, Korea; cholhosong@gmail.com (C.S.); leewkkorea@gmail.com (W.-K.L.); yson@korea.ac.kr (Y.S.) \\ 4 Center for Climate Technology Cooperation, Green Technology Center, Toegyero 173, Seoul 04554, Korea; \\ jongyeol1220@naver.com \\ 5 Ecosystems Services and Management, International Institute for Applied Systems Analysis (IIASA), \\ A-2361 Laxenburg, Austria; windy7up@gmail.com \\ 6 Environmental GIS/RS Center, Korea University, Anamro 145, Seoul 02841, Korea \\ * Correspondence: vicente@mcc-berlin.net; Tel.: +49-(0)-303385537-223
}

Received: 30 April 2019; Accepted: 4 June 2019; Published: 5 June 2019

\begin{abstract}
In 1955, after the Korean War, only 35\% of the national land area in South Korea was covered by forests. In the 1960s, the Korean Government implemented the national forestation program in order to increase the extent of the forest surface and thereby counteract the negative ecological consequences from deforestation, such as erosion and ground instability. According to previous studies, this led to an increase in carbon (C) accumulated in the forest biomass of $1.48 \mathrm{Gt}$ $\mathrm{CO}_{2}(0.40 \mathrm{Gt} \mathrm{C})$ in the period 1954-2012. However, these studies did not take into account the amount of soil organic carbon (SOC) that was accumulated during that period and the influence of management practices on soil ecosystem services. Currently, South Korean authorities are considering the idea of implementing some forest management practices in order to increase timber extraction (e.g., by reducing the cutting age of the trees or by applying thinning and tending measures). In this study, we assess the influence of these management regimes on SOC dynamics and propose a theoretical framework to assess the influence of forest management practices on three ecosystem services, namely, C sequestration, water supply, and biomass production, while considering soil functioning, and especially SOC, as a group of supporting services underpinning the three named ecosystem services. We find that, in terms of SOC sequestration, reducing the cutting age from 80 to 40 years would be suitable only in the case of high biomass production forests, whereas in the case of lower biomass production forests reducing the cutting age would achieve very low SOC levels. However, we propose that increasing tree species diversity, even though it would not lead to a direct increase in the SOC content, could help to lessen the negative effects of reducing the cutting age by improving other soil properties, which in turn positively affect soil functioning (e.g., soil biodiversity, nutrient availability) and the resilience of the forest ecosystem. Finally, we discuss potential policy approaches to incentivize sustainable management practices in South Korean forests from a soil protection perspective.
\end{abstract}

Keywords: soil organic carbon; ecosystem services; reforestation; resilience 


\section{Introduction}

Forest ecosystems are a key element in delivering ecosystem services that support and benefit humans [1-3]. These services are grouped in four categories: provisioning (e.g., food, water, wood, fiber, or fuel), regulating (e.g., water, climate, erosion, or pollination), cultural (aesthetic, spiritual, or recreational), and supporting (nutrient and water cycling, habitat, or biodiversity) services [2]. Since the 2005 Millennium Ecosystem Assessment, several studies have assessed the influence of different management practices on ecosystem services (e.g., in vineyards [4], in cover crops on agriculture land [5], in agroforestry [6], and in forests [7]). Recently, others have provided frameworks for the description and valuation of ecosystem services (e.g., [8-10]).

However, very often, the role of soils in delivering ecosystem services has been ignored, and studies have been focused mainly on what happens above ground [11], and mostly on maximizing the production of one ecosystem service [12]. In many cases, soils are not directly responsible for delivering ecosystem services (provisioning, regulating, and cultural), but soil functions (also known as soil processes or supporting services) act as intermediaries in delivering the final ecosystem services (Figure 1) [13]. These supporting services are threefold: (i) nutrient cycling, (ii) water cycling, and (iii) soil biological activity (i.e., habitat for soil biota) [11]. In healthy soils, the supporting functions contribute to soil formation [13], whereas if there is a deficit in the natural capital, soil supporting functions will be negatively affected and a degradation process will take place (Figure 1). In "The Economics of Ecosystem and Biodiversity" (TEEB) assessment [3], soils are framed as ecological processes providing the final ecosystem services. Hence, soils belong to the so-called "ecological infrastructure" (EI) and can be defined as "soil natural capital, its properties and components, and soil supporting functions that underlie and drive other ecosystem services (cultural, regulating, and provisioning)" (definition modified from [14]).

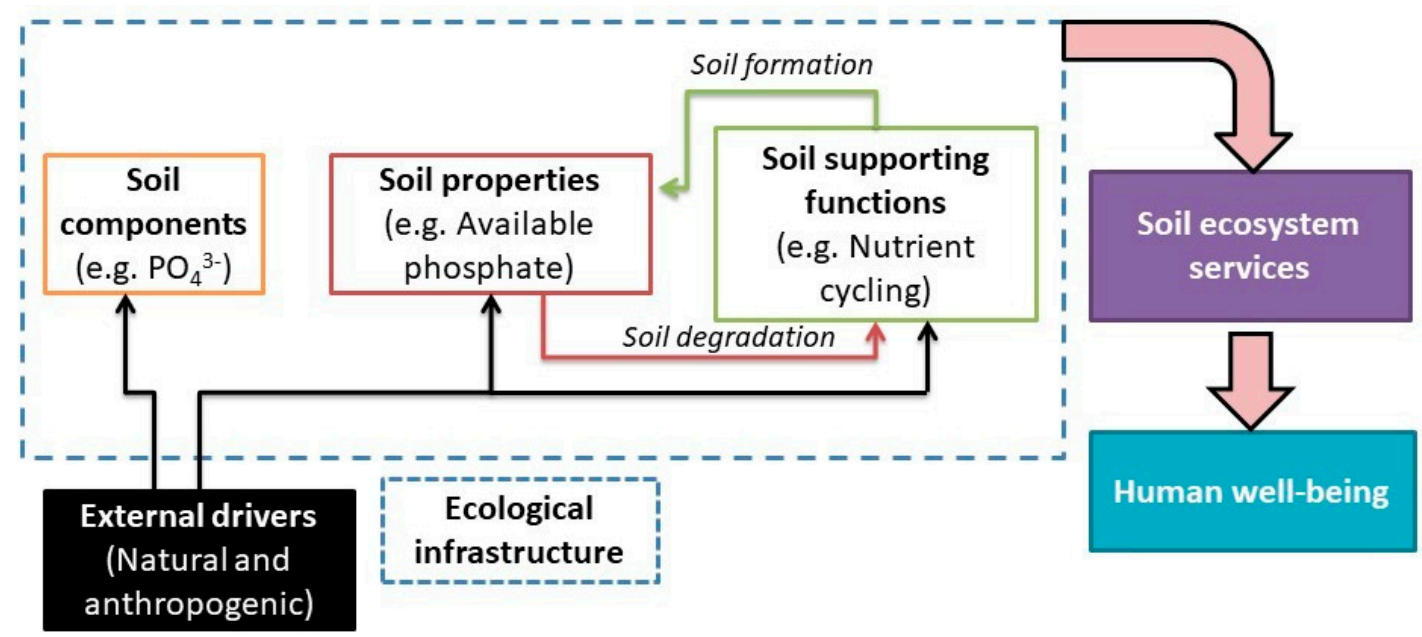

Figure 1. Framework for the provision of ecosystem services from soil natural capital. Adapted from $[11,14]$.

Soil properties controlling soil supporting functions can be inherent (e.g., texture) or manageable (e.g., nutrient content). The manageable properties are the most interesting ones. Thus, one of the most important manageable soil properties is the soil organic carbon (SOC) content. It is so important that soil has been defined as a realm that is driven by the organic carbon (C) [15]. Furthermore, the increase in SOC content also has the benefits of promoting the Sustainable Development Goals (SDGs) of the UN (e.g., improving land and soil quality or reducing land degradation) [15]. This high importance of soils is due to the fact that the SOC content is related to many soil properties, functions, and ecosystem services [16], thus being the key determinant of soil resilience.

Over the last two decades, research on SOC has increased and has especially been focused on one regulating ecosystem service- $\mathrm{SOC}$ sequestration as a mitigation strategy against climate change. 
Today, SOC sequestration has gained traction in the debate as a negative emission technology (NET), which is easily implementable and at low cost [17-19]. It can therefore play an important role in climate change mitigation in achieving the Paris Agreement's target of $1.5^{\circ} \mathrm{C}$ [20]. Thus, this effect has been widely studied in agroecosystems (e.g., [21-28]). The ability of soils to accumulate organic carbon (C) and to reduce $\mathrm{CO}_{2}$ emissions from soil has left aside the effect of the variation of SOC content on other soil ecosystem functions and ecosystem services. Importantly, the risk of focusing on one single ecosystem service is that it may result in a substantial decrease in the provision of other ecosystem services [12]. Therefore, although there are a few studies assessing the relationship between soils and ecosystem services (e.g., $[11,14,16,29,30])$, there is a clear lack of studies linking soil supporting functions or properties to ecosystem services [16].

$\mathrm{C}$ sequestration in forests has been focused especially on $\mathrm{C}$ accumulation in biomass during afforestation and reforestation (AR) processes, another NET that has been widely studied [18,19,31]. However, the study of $C$ sequestration in forests rarely considers the soil $C$ pool, which together with the $C$ in the biomass exceeds the amount of $C$ in the atmosphere [32]. This might be due to the fact that forests are the only vegetation type where biomass is a similar size C pool when compared to soil [33] and, on the other hand, due to the complexity of the plant-soil relationships, which are very difficult to include in models assessing the $\mathrm{C}$ cycle. One example of a plant-soil relationship is rhizodeposition, defined as the release of rhizodeposits by living roots into the soil, which is one of these complex mechanisms $[34,35]$. The release of the root exudates can affect the microbial diversity and activity in the rhizosphere [36], thus affecting strongly the SOC accumulation in the rhizosphere and leading to different "priming effects" [37].

Therefore, it is a challenge to unify the assessment of the SOC pool and the C accumulated in forest biomass. An example is the reforestation process that took place in South Korea after the Korean War, when more than half of the forests were cut and soil erosion became a considerable risk [38]. Thus, in 1955 only $35 \%$ of the national land area was covered by forests [39]. In response to that situation, the Korean Government implemented the National Forestation Program in the 1960s. The result was that the mean stand volume density increased from 9.55 in 1960 to $145.99 \mathrm{~m}^{3} \mathrm{ha}^{-1}$ in 2015 [40]. This increase in the forest biomass-mainly formed by one or few tree species-has led to additional $C$ sequestration, which has already been assessed previously [41-43]. However, the dead organic matter and the influence on SOC stocks were not assessed. Other authors [44,45] have estimated C balances with models, but with insufficient validation (e.g., without considering the dead organic matter pool) [46].

Lee et al. $[46,47]$ used the Forest Biomass and Dead organic matter Carbon (FBDC) model and the 5th South Korean National Forest Inventory (NFI) as input data to estimate the C stocks and their changes in South Korean forests, including biomass and dead organic matter in the period 1954-2012. The simulation results show that biomass $\mathrm{C}$ stocks increased from 36.4 to $440.4 \mathrm{Tg} \mathrm{C}$ (i.e., $1.48 \mathrm{Gt} \mathrm{CO}_{2}$ sequestered) at a rate of $7.0 \mathrm{Tg} \mathrm{C} \mathrm{yr}^{-1}\left(0.026 \mathrm{Gt} \mathrm{CO}_{2}\right.$ year $\left.^{-1}\right)$. The dead organic matter $\mathrm{C}$ stocks increased from 386.0 to $463.1 \mathrm{Tg} \mathrm{C}$ (i.e., $0.28 \mathrm{Gt} \mathrm{CO}_{2}$ sequestered) at a rate of $1.3 \mathrm{Tg} \mathrm{C}_{\text {year }}{ }^{-1}$ $\left(0.0048 \mathrm{Gt} \mathrm{CO}_{2}\right.$ year $\left.^{-1}\right)$.

Currently, the need for timber and the increased knowledge about forest ecology have led policymakers in South Korea to propose new management practices for South Korean forests. These consist of (i) reducing the cutting age from 80 to 40 years, (ii) tending and thinning, and (iii) increasing tree species diversity [48].

In this study, we propose a theoretical framework for assessing the results of the SOC dynamics and its relationships with three important ecosystem services (C sequestration, water supply and biomass production) in order to formulate policy instruments aimed at fostering $C$ sequestration without negatively affecting water supply and biomass production. To demonstrate an application of the framework, we used the FBDC model to assess the dynamics of the SOC accumulation in South Korean forests. For that purpose, we generated twelve scenarios by changing the forest biomass production (low, intermediate, high) and two types of management: cutting (cutting age of 40-year-interval 
clearcut, 80-year-interval clearcut) and tending and thinning (with 20-year-thinning and without 20-year-thinning). Finally, we discuss policy approaches aimed at fostering $\mathrm{C}$ sequestration without negatively affecting water supply and biomass production.

\section{Material and Methods}

\subsection{The Forest Biomass and Dead Organic Matter Carbon (FBDC) Model}

The Forest Biomass and Dead organic matter Carbon (FBDC) model, a generic model, simulates forest $C$ dynamics using tree biomass growth functions and a set of related parameters on non-biomass C pools [38,46,47]. It assesses $C$ stocks and their changes in five pools (aboveground biomass, belowground biomass, litter, dead wood, and mineral soil (i.e., SOC)). The biomass compartment consists of stems, branches, foliage, and coarse and fine roots, which are simulated using empirical growth functions [38]. Particularly, the Gompertz function's formula was used in the quantification of stem volume growth. Then conversion, which is developed on the basis of extensive field measurement data in South Korea, was used to estimate changes in $C$ stocks of each biomass compartment from the estimated stem volume. Furthermore, annual C stocks of the remaining pools (litter, dead wood, and mineral soil) were calculated by estimating the differences between annual organic matter inputs and outputs. The organic matter input was determined by turnover and mortality rate of each biomass compartment. The organic matter output was calculated by multiplying the $C$ stock of pool in the previous year to the decay rate of this pool in the current year. The parameters were obtained by literature review and field measurements. Further information on the FBDC model is presented in [44].

The effect of forest management on forest $C$ dynamics, including thinning and clearcut, was considered in this model. The reduction of biomass $C$ stock after forest management proportionally increased with the intensity of forest management. The growth after thinning or clearcut was also formulated with the growth equations. In addition, these forest management practices generated the dead organic matter input to the non-biomass $C$ pools, which was proportionate to the intensity of forest management.

\subsection{Scenarios}

The assumptive simulation unit, a size of $1 \mathrm{~km}^{2}$ forest stand of red pine (Pinus densiflora Sieb. et Zucc.), was established. The biomass production was the average level of the South Korean forests on the basis of the National Forest Inventory (NFI) data. The mean annual temperature was assumed to be $11^{\circ} \mathrm{C}$, close to the average level among the South Korean forests. Then, three levels of biomass production were determined: intermediate, low ( $-30 \%$ as compared to the intermediate), and high $(+30 \%$ as compared to the intermediate). The reason for selecting different biomass production levels is that the amount of the incoming organic $C$ to the soil is the main driver of SOC accumulation dynamics [25]. Moreover, we selected two different cutting ages (40 and 80 years) and the possibility of combining tree cut (i.e., wood harvest) with thinning and tending activities each 20 years. By combining these two types of practices, an effect on SOC dynamics can be expected. As a result of the combination of these variables, twelve scenarios were generated.

To initialize the model, average values in South Korean forests for litter, dead wood, and SOC in the mineral soil (first $100 \mathrm{~cm}$ ) were selected $\left(2.81,4.14\right.$, and $77.53 \mathrm{tC} \mathrm{ha}{ }^{-1}$, respectively). The remaining parameter, the biomass production, changed according to its three different levels (low, intermediate, or high). After setting up these four parameters, the model was run with an 80-year horizon in order to assess the effect of reducing the cutting age from 80 to 40 years on SOC content.

For the assessment, an example of pine trees (Pinus densiflora) was used. They typically cover approximately $20-24 \%$ of South Korean forests, thus being one of the most representative species. They are located over almost all the Korean Peninsula, but mainly in the southern and eastern parts. The tree stands used for the FBDC model were selected based on $[49,50]$. 


\section{Results and Discussion}

\subsection{SOC Dynamics and Accumulation}

\subsubsection{Influence of Biomass Production on SOC Dynamics}

After 80 years, organic $\mathrm{C}$ content in the mineral soil in all the scenarios with low biomass production could not recover the initial SOC values (Figure 2). This is due to the very low biomass production, which is not high enough to compensate SOC losses under the different management practices. The highest SOC losses occur in the 40-year-interval clearcut with tending and thinning scenario, whereas the lowest losses can be observed in the 80-year-interval clearcut without tending and thinning. These losses vary from 3 to $17 \mathrm{tC} \mathrm{ha}^{-1}$ in the scenarios in soils under low biomass production. With intermediate biomass production, the 40-year-interval clearcut scenarios result in lower SOC content than the 80-year-interval clearcut scenarios (Figure 3), but these losses are lower than those of the scenarios with low biomass production (between 5 and $10 \mathrm{tC} \mathrm{ha}^{-1}$ ). However, the 80-year-interval clearcut scenarios feature higher final SOC values (between 3 and $8 \mathrm{tC} \mathrm{ha}^{-1}$ ) (Figure 3). Finally, soils with high biomass production recover or result in higher values, up to $18 \mathrm{tC}$ $\mathrm{ha}^{-1}$ (Figure 4). Only the 40-year-interval clearcut scenario with tending and thinning features lower values than the initial ones $\left(5 \mathrm{tC} \mathrm{ha}^{-1}\right)$.

(a) With thinning and tending
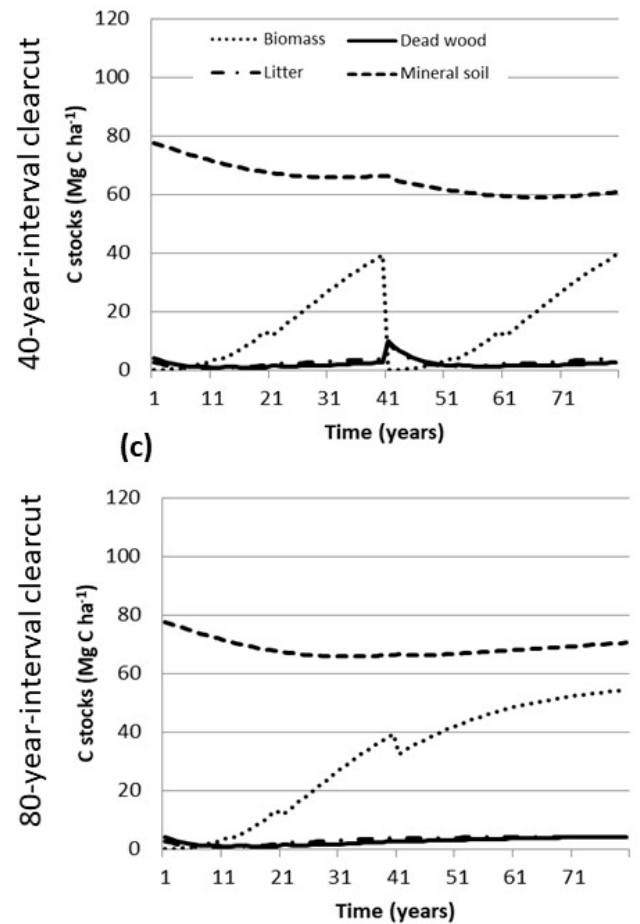

(b) Without thinning and tending
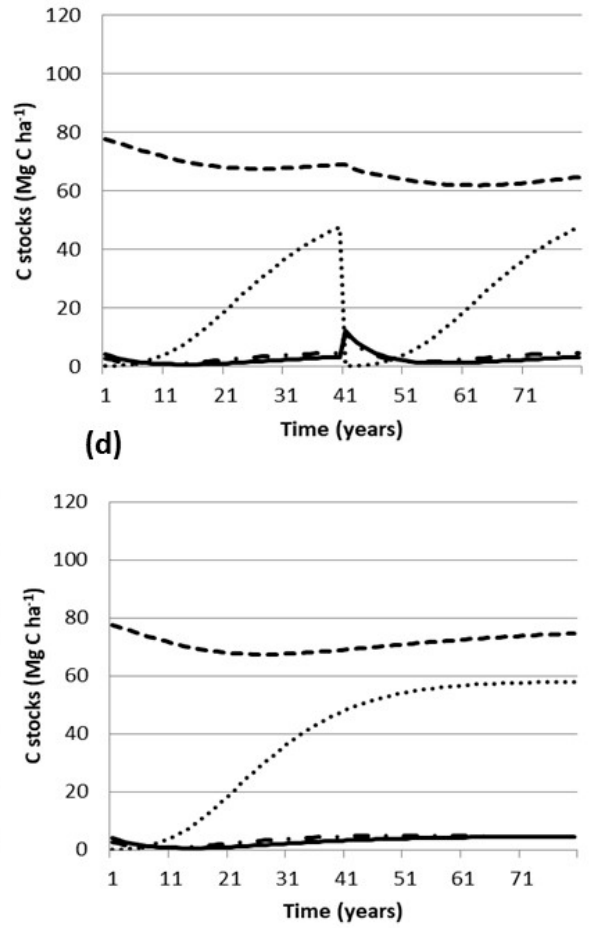

Figure 2. Carbon stock scenarios resulting from the application of the Forest Biomass and Dead organic matter Carbon (FBDC) model for low biomass production forests in South Korea according to (a,b) and $(\mathbf{c}, \mathbf{d})$ cutting age (40 and 80 years) and $(\mathbf{a}, \mathbf{c})$ and $(\mathbf{b}, \mathbf{d})$ with and without thinning and tending during the first 80 years after implementing the forest management. Different line types represent different forest carbon pools (biomass, litter, dead wood, and mineral soil). 
(a) With thinning and tending

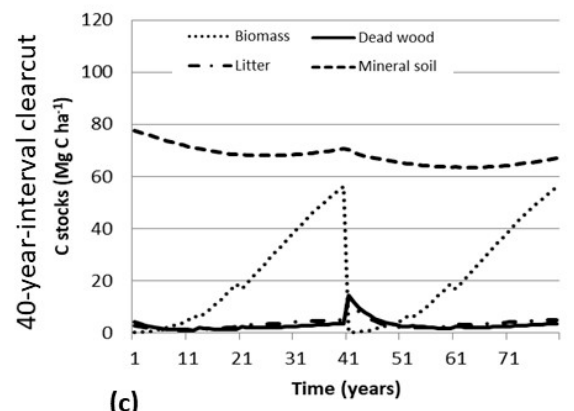

(c)

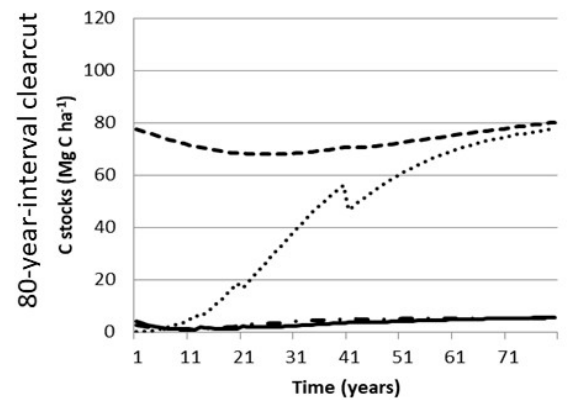

(b) Without thinning and tending

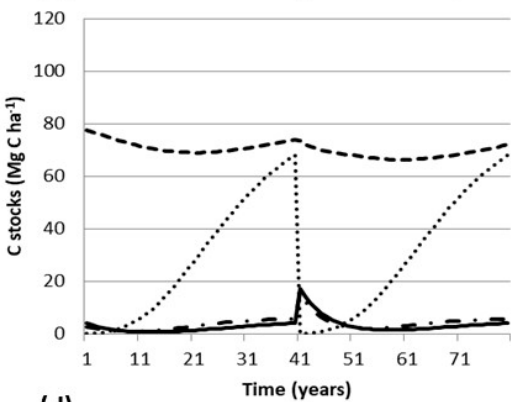

(d)

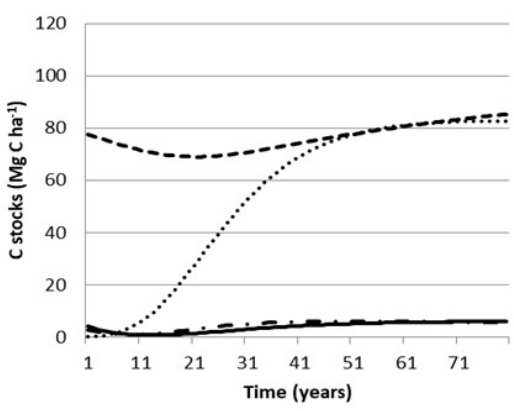

Figure 3. Carbon stock scenarios resulting from the application of the FBDC model for intermediate biomass production forests in South Korea according to $(\mathbf{a}, \mathbf{b})$ and $(\mathbf{c}, \mathbf{d})$ cutting age $(40$ and 80$)$ and $(\mathbf{a}, \mathbf{c})$ and $(\mathbf{b}, \mathbf{d})$ with and without thinning and tending during the first 80 years after implementing the forest management. Different line types represent different forest carbon pools (biomass, litter, dead wood, and mineral soil).

(a) With thinning and tending

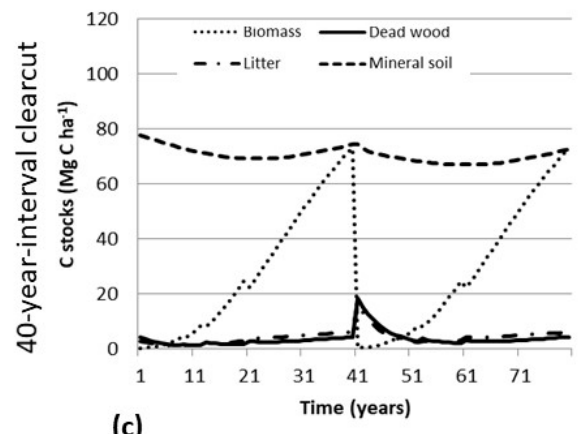

(c)

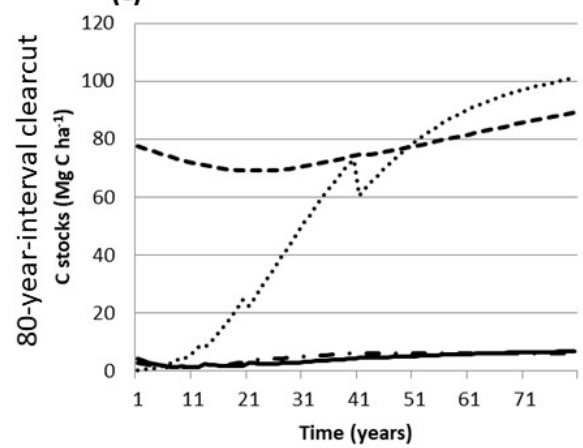

(b) Without thinning and tending

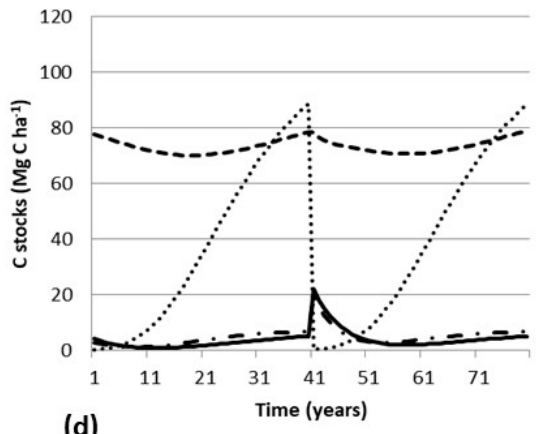

(d)

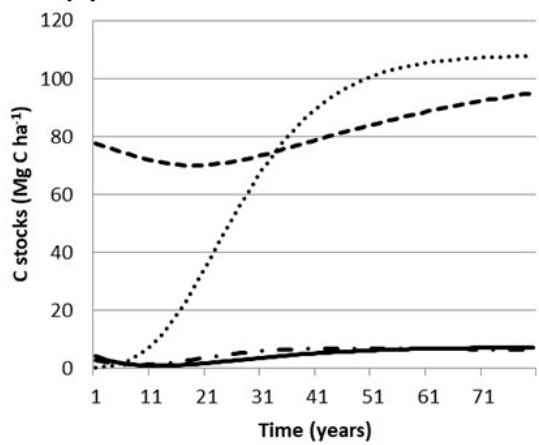

Figure 4. Carbon stock scenarios resulting from the application of the FBDC model for high biomass production forests in South Korea according to (a,b) and (c,d) cutting age (40 and 80) and (a,c) and $(\mathbf{b}, \mathbf{d})$ with and without thinning and tending during the first 80 years after implementing the forest management. Different line types represent different forest carbon pools (biomass, litter, dead wood, and mineral soil). 
In all scenarios with low and intermediate biomass production, SOC exceeded the $\mathrm{C}$ accumulated in tree biomass (Figures 2 and 3). It was only with high biomass production that $C$ in tree biomass showed higher values than in mineral soil (Figure 4). Organic $C$ in dead wood and litter amounted to typically less than $10 \%$ of the total SOC content. It was only after cutting the trees in the 40 -year-interval clearcut scenarios that the values of these pools increase, achieving values up to $25 \%$ of the total SOC content. However, this effect typically lasted only the first ten years after cutting the trees ( $a$ and $b$ in Figures 2-4).

On the other hand, in the low biomass production scenarios, final SOC values were between 60 and $75 \mathrm{tC} \mathrm{ha}^{-1}$ (Figure 2), whereas in the high biomass production scenarios they were between 73 and $95 \mathrm{tC} \mathrm{ha}^{-1}$ (Figure 4). In other words, forest soils under high biomass production accumulated between 13 and $20 \mathrm{tC} \mathrm{ha}{ }^{-1}$ (i.e., between 0.16 and $0.25 \mathrm{tC} \mathrm{ha}^{-1}$ year ${ }^{-1}$ ) more organic $\mathrm{C}$ after 80 years than soils under low biomass production. Therefore, biomass production was the main driver affecting SOC accumulation.

\subsubsection{Influence of the Management on SOC Dynamics}

We found the following gradient of SOC accumulation under different management practices: 40-year-interval clearcut with tending and thinning $<40$-year-interval clearcut without tending and thinning $<80$-year-interval clearcut with tending and thinning $<80$-year-interval clearcut without tending and thinning. These results are obviously related to the increasing amount of the incoming organic $\mathrm{C}$ to the soil when eliminating tending and thinning activities and when increasing the cutting age from 40 to 80 years [51].

Similar trends were found for the different scenarios under different management practices. At the beginning, the amount of SOC decreases because of the very low amount of the incoming organic $\mathrm{C}$ to the soil. However, over time, as the tree age increases and so the tree biomass, it compensates the SOC losses and SOC content starts to increase. However, this increase depends on the type of management. Thus, for the 40-year-interval clearcut scenarios this SOC increase is very slight, even in the high biomass production scenarios, whereas in the 80-year-interval clearcut scenarios the increase is much stronger. In this line, the differences in the accumulated SOC with cutting ages of 40 and 80 years under same thinning activities were found to be approximately 16,13 , and $10 \mathrm{tC} \mathrm{ha} \mathrm{h}^{-1}$ $\left(0.2,0.16,0.13 \mathrm{tC} \mathrm{ha}^{-1}\right.$ year $\left.^{-1}\right)$ after 80 years in the scenarios with high, intermediate, and low biomass production, respectively.

On the other hand, the influence of 20-year-thinning and -tending activities on SOC accumulation was lower than the effect of reducing the cutting age. Thus, these differences were approximately 6,5 , and $4 \mathrm{tC} \mathrm{ha}^{-1}\left(0.08,0.06\right.$, and $0.05 \mathrm{tC} \mathrm{ha}^{-1}$ year $\left.^{-1}\right)$ after 80 years in the scenarios under high, intermediate, and low biomass production, respectively.

\subsubsection{Selecting Most Suitable Management Practices}

The variety in the responses of the SOC dynamics to the different forest management practices under different biomass production scenarios suggests that there is not one single management practice more suitable than others, but that it depends on the specific environmental conditions affecting biomass production. Thus, it is only in the case of the scenarios with high biomass production that the final values of the SOC content are similar to the initial ones and, thus, maintain SOC values around 70 and $80 \mathrm{tC} \mathrm{ha}{ }^{-1}$. However, in the intermediate and low biomass production scenarios the final SOC values are mostly between 60 and $70 \mathrm{tC} \mathrm{ha} \mathrm{C}^{-1}$ and, thus, imply an impoverishment in soil organic matter. Therefore, we conclude that the 40-year-interval clearcut is suitable only in forests with relatively high biomass production, whereas in intermediate and low biomass production forests, the 80 -year-interval clearcut is more suitable in order to keep the SOC level above $70 \mathrm{tC} \mathrm{ha-1}$ (Figure 5). Furthermore, under the perspective of the SOC accumulation, tending and thinning activities have more impact in terms of the proportion of SOC lost in the 40-year-interval clearcut scenarios. Therefore, according to 
these results, we suggest tending and thinning only for longer clearcut intervals and consider applying them in shorter intervals only under high biomass production (Figure 5).

However, organic $C$ accumulation in soils is only one of the ecosystem services affected by the implementation of the assessed forest management practices. There are other soil-related ecosystem services (e.g., water supply and soil functioning) that can also be affected by forest management practices and, consequently, it would be possible to compensate or palliate the effects of the decrease in the SOC content by applying other sustainable management practices (e.g., increase tree species diversity). This possibility is assessed in the following section.

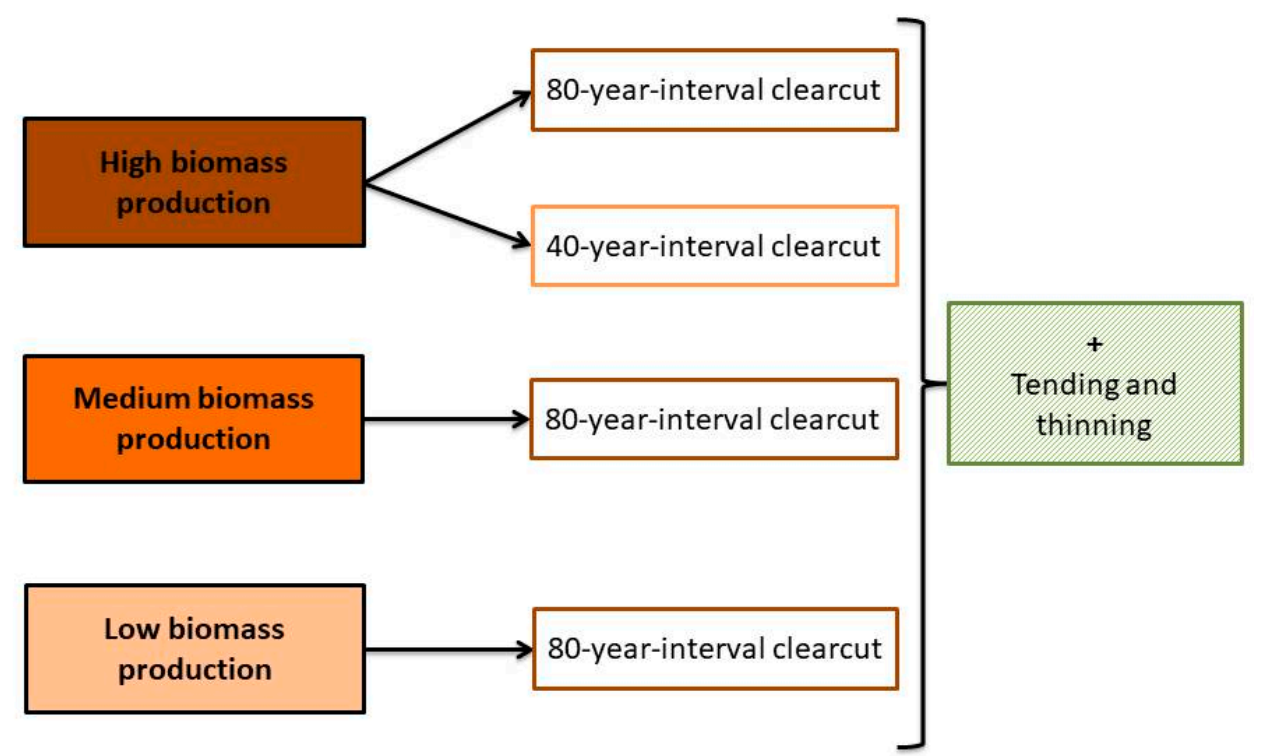

Figure 5. Suggested management practices in South Korean forests based on the amount of soil organic carbon accumulated.

\subsection{Assessment of Synergies and Trade-Offs between Soil Functions, Management Practices, and Related Ecosystem Services}

After having assessed the influence of the different management practices on SOC dynamics, we consider it highly important to put them into the context of the ecosystem services assessment, which involves two types of relationships [12,52,53]: (i) effects of drivers on multiple ecosystem services and (ii) interactions among ecosystem services. Identifying the relationships among different ecosystem services and drivers, synergies, and trade-offs is the first step to understand the socio-ecological system and the implication of human interventions for nature and human well-being. Knowing these relationships helps changes in management to improve trade-offs and reinforce synergies, and thus strengthen ecosystems' resilience [12]. For that purpose, first of all, it is necessary to identify those drivers playing a key role in delivering the different ecosystem services.

\subsubsection{Identifying Key Components of the Ecological System to Strengthen Ecosystem Resilience}

As has previously been shown, the ecological infrastructure (EI), in which soil functions are included, underlies and drives the delivering of ecosystem services. Therefore, soil, as an important part of the EI, plays a key role, and SOC represents one of the most important natural capital stocks of soils $[15,54]$. Consequently, soil functions and SOC were included in the assessment. Regulating services are very often not considered, since the focus is usually on provisioning services and they often change at very low rates. However, these slowly changing variables [55] are frequently the best indicators of resilience $[12,56]$. Hence, we included the $C$ sequestration assessment as one of the main regulating ecosystem services. In order to assess the ecosystem functioning beyond C sequestration, we also included one of the other key regulating ecosystem services, namely, water supply. Finally, 
biomass production (i.e., timber extraction) was included as the main provisioning ecosystem service, since it is directly related to socioeconomic variables.

3.2.2. Relationships between the Ecological Infrastructure, Ecosystem Services, and Management Practices

In order to study the relationships between EI, ecosystem services, and management practices, diagrams showing the interconnections between them are proposed [12]. Sometimes, there is a positive interaction, where the improvement or increase in one of them affects another one positively. At other times, the opposite happens, and a soil function or ecosystem service deteriorates when the management is implemented. Finally, sometimes the relationship is not clearly positive or negative, or the ecosystem service reaches maximum values at intermediate levels of the other components.

(a) No forest management (Scenario A)

This scenario corresponds to the natural situation, where the forest biomass is increasing and there is no management controlling forest growth (Figure 6). In this scenario, the increase in forest biomass directly leads to an increase in $\mathrm{C}$ sequestration in biomass. Conversely, higher biomass production leads to an increase in the amount of SOC. This is mainly due to two processes: (i) an increase in the amount of litter and dead wood coming from leaves, branches, and other falling biomass, and (ii) an increase in the amount of rhizodeposits due to a greater area under the rhizospheres' activity, even though rhizodeposition processes depend also on plant ecophysiology features and other environmental and soil conditions [57,58]. Importantly, the increase in the SOC leads to an improvement in the soil functions (Figure 6). It is well known that a high SOC content is positively related to high microbial activity (e.g., [59,60]) and an improvement in other soil physico-chemical properties [61] leading to higher quality of the water supply (through filtration, buffering, and transformation functions of soils) [62], and to fostering nutrient cycling [11]. However, the increase in biomass production would not directly lead to an increase in water supply, since previous studies show that high forest biomass increases the water consumption by roots. In addition, it would also increase the water interception by leaves [48,63] (Figure 6). Therefore, and according to our theoretical model, this effect can be compensated for or mitigated by an improvement in the soil functioning and also through thinning and pruning.

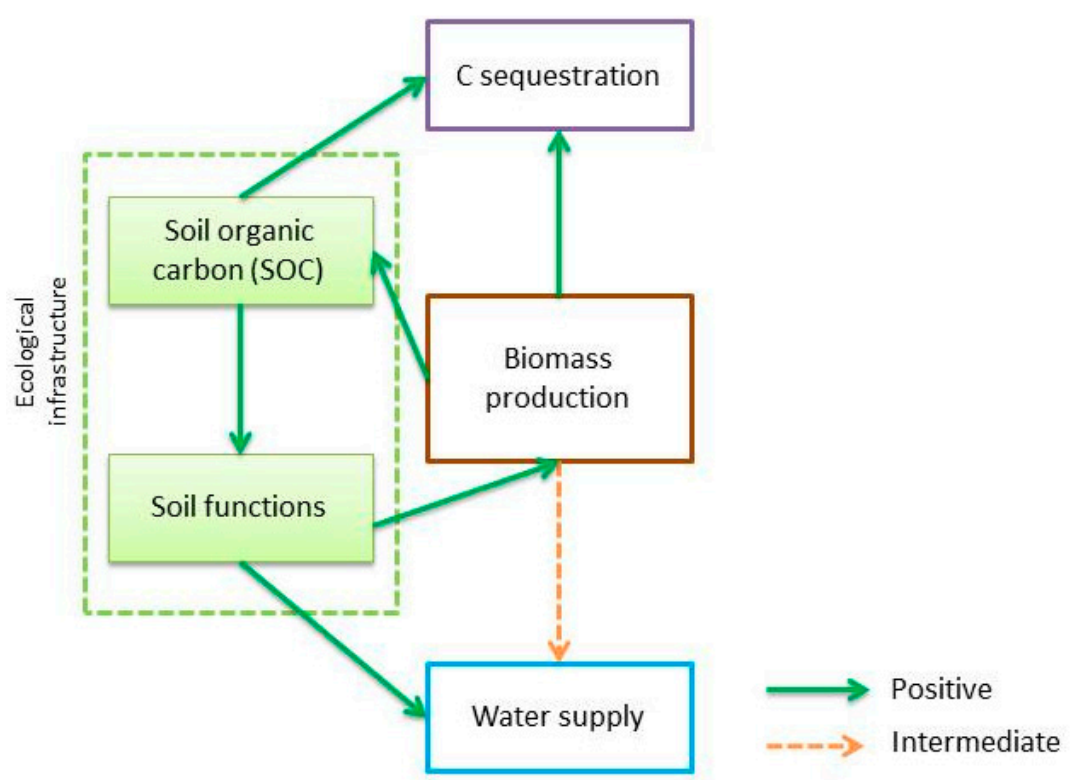

Figure 6. Relationship between ecosystem services, soil organic carbon, and soil functions in a scenario of no timber extraction. Note that the maximum water supply would be achieved with an intermediate tree density [63]. 
The net benefit of implementing this scenario results from deducting the costs from the benefits. The benefits consisted of disaster risk reduction (DRR), C credit, reduced soil erosion, and water yield enhancement $[38,64,65]$. The benefit of DRR for each disaster type has been estimated by a reference level of monetary damage minus annual damage. The reference level means a magnitude of disaster before significant forest recovery in this context. If disaster damage exceeded the reference level, the benefit becomes negative. In contrast, the benefit is positive if disaster damage is less than that of the reference level [65]. The estimated benefit of DRR by forestation in the Republic of Korea ranged from \$1305 to \$2241 million in 2010, whereas estimated values for enhancing water yield and reduced soil erosion amounted to $\$ 263$ million and $\$ 278$ million, respectively. The annual $\mathrm{C}$ credit from forest $\mathrm{C}$ sequestration in the Republic of Korea was about $\$ 2778$ (considering $\$ 31 \mathrm{t} \mathrm{CO}_{2}^{-1}$ with a discount rate of $3 \%$ ). This does not account for the cost, that is, the investment into the forestation program, which was approximately $\$ 279$ million in 2010. Considering these values, the benefit-cost ratio range of the reforestation program in the Republic of Korea was 5.26-8.06, thus making the reforestation process in the Republic of Korea highly valuable in terms of monetary benefits [65].

(b) Timber production in mono-species or few-species tree plantations (Scenario B)

In this scenario, trees are cut to produce timber in mono-species tree plantations. Biomass production would be increased, since the growth rate of the younger trees is higher [66,67]. However, as has been commented previously, cutting old trees leads to a decrease in the SOC content due to a decrease in the amount of litter and dead wood from the trees accumulated on the soil surface and also due to the lower root activity of new trees. These lead to a soil functioning deterioration, which negatively affects the ability of soil to regulate water supply (Figure 7). Furthermore, the deterioration in the soil functioning implies deterioration in soil fertility properties, leading to a decrease in biomass production.

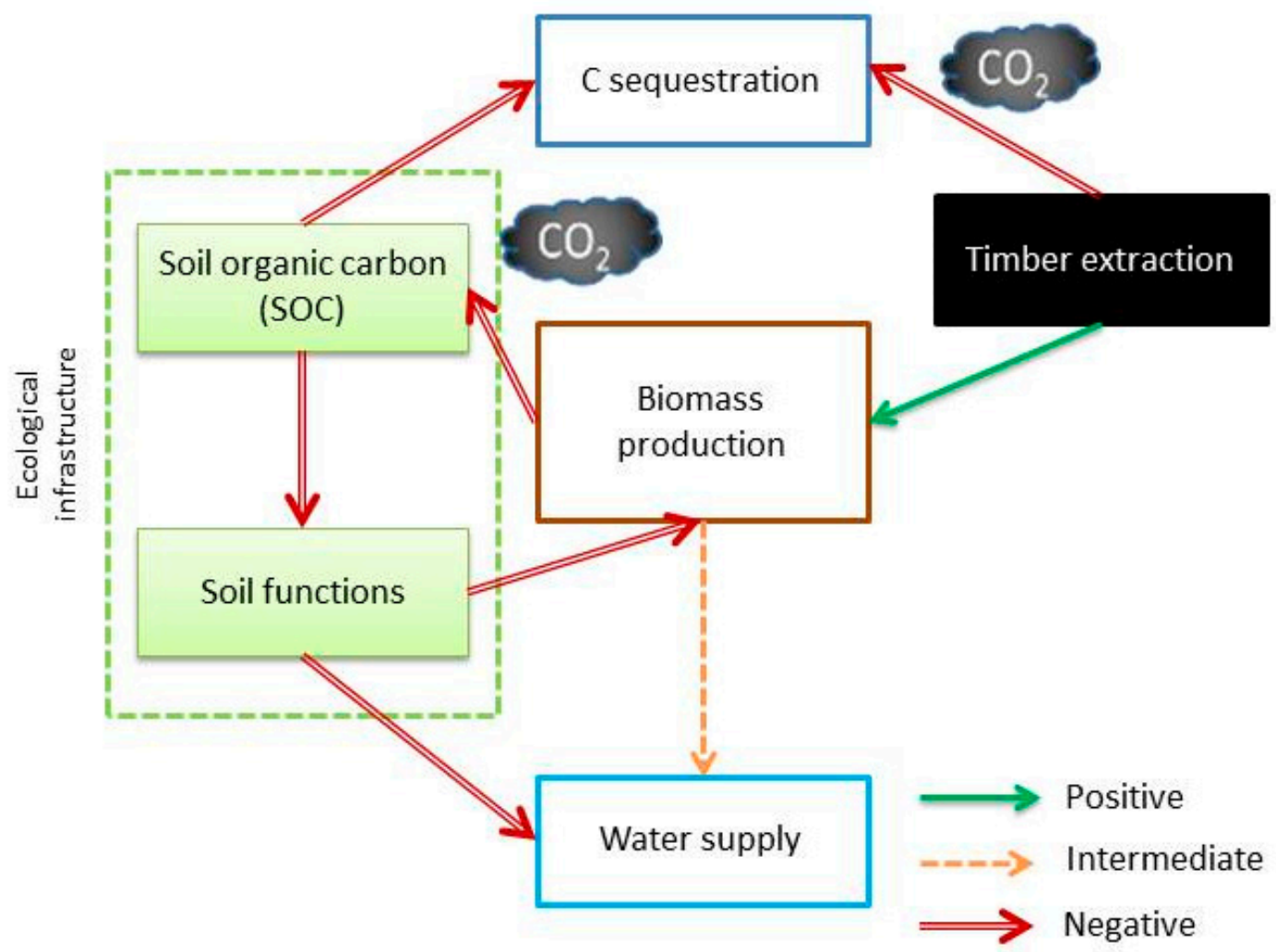

Figure 7. Relationship between ecosystem services, soil organic carbon, and soil functions in a timber extraction scenario. Note that the maximum water supply would be achieved with an intermediate tree density [63]. 
Therefore, the deterioration of the EI after cutting trees affects the basis of ecosystem functioning, making the soil, and thus the whole ecosystem, less resilient (i.e., the capacity to maintain its structure and functions despite pressure to the system [68]). Consequently, the forest is more susceptible to unexpected changes in some variables, leading to an increase in the risk of unwanted and rapid regime shifts in the ecosystem and putting at risk the capacity of the system to provide provisioning ecosystem services, resulting in a vicious circle of system degradation.

Therefore, it is of vital importance to find new management practices that can be applied jointly to timber extraction while simultaneously minimizing the negative effects of decreasing the incoming organic $\mathrm{C}$ to the soil. A promising low-cost management practice would be to increase tree species diversity.

(c) Timber production with replacement with trees of different species (Scenario C)

In this case, trees are cut and replaced with trees of different species [48]. In principle, there is no direct positive effect on SOC sequestration, since biomass continues to be extracted as timber (Figures 2-4 and 8). However, the introduction of different tree species increases the soil biota diversity leading to a nutrient cycling improvement and, thus, contributing to sustain soil multi-functionality [69,70]. This is explained by the fact that different plant species support different bacterial, fungal, and archaeal communities [36,71-73] and that different functional groups have their specific nutrient requirements. The improvement in soil functioning fosters the soil formation process [11,14] (Figure 1), leading to two remarkable positive effects: (i) an increase in the biomass production and (ii) an increase in water supply. Furthermore, the increase in tree species diversity has two important and direct effects on ecosystem services. First, there is an increase in biomass production (Figure 8). According to Kim [48], the biomass production might be higher in scenarios increasing the tree species diversity. Second, a mixture of tree species can exploit the nutrient and soil moisture pool of soil profiles more diversely than a mono-species tree stand can [33], thus minimizing the risk of nutrient and water depletion (Figure 1). Therefore, the increase in soil biodiversity leads to a better responsiveness to extreme phenomena resulting from climate change that can worsen their degradation, thus improving the resilience of the ecosystem [74] and contributing to a lower risk of landslides, droughts, or soil erosion.

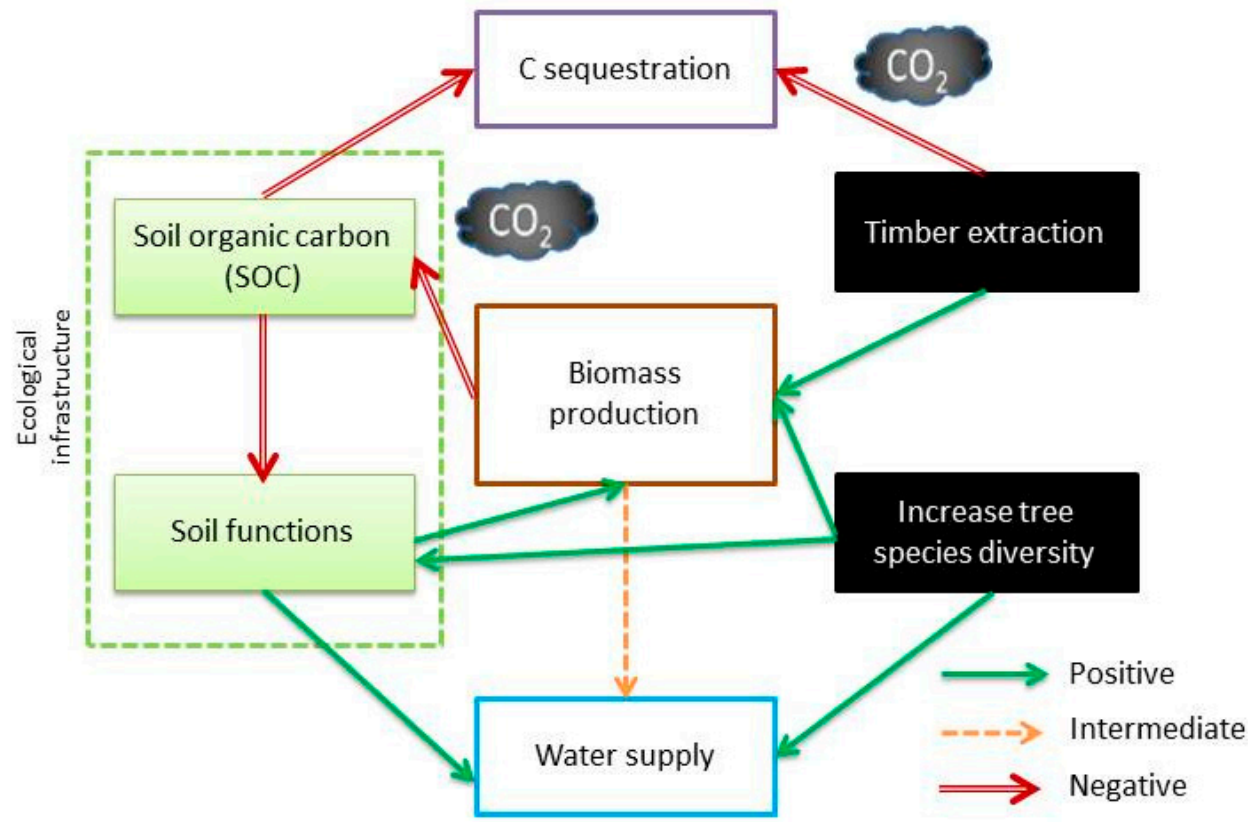

Figure 8. Relationship between ecosystem services, soil organic carbon, and soil functions in a scenario consisting of extracting timber and replacing with trees of different species (i.e., increase tree species diversity). Note that the maximum water supply would be achieved with an intermediate tree density [63]. 
Finally, the establishment of mixed-species forests affects the adaptation to climate change positively, since it implies that different species are occupying different ecological niches [33] and the risks from climate change are consequently distributed over different species having a wide variety of vulnerabilities, thus ensuring soil protection against future disturbances [75-77]. However, the increase in tree species diversity should be carried out carefully, since the relation between diversity and ecosystem processes is not always linearly positive (i.e., the species are singular and each species contributes in a unique way to the ecosystem processes). In fact, it is sometimes asymptotic (i.e., there is redundancy and the species contribute in similar ways) or idiosyncratic (i.e., the contribution of the different species is unpredictable because they depend on the abiotic or biotic context) [78]. This suggests that it is not species richness, but rather the characteristics of the component species that are of prime importance [79], and tree species should therefore be selected according to their ability to increase the diversity of the characteristics and functions of the component species in the forest ecosystem.

\subsection{Going beyond Carbon Sequestration: Towards a Holistic Perspective of Soil Ecosystem Services and Human Well-Being}

As described previously (Section 3.1), forest management practices directly affect SOC accumulation and dynamics, and the important role of SOC underpinning other soil-related ecosystem services makes SOC dynamics assessment a necessary first step of a broader soil ecosystem services assessment. In this study, we find that it is only in high biomass production forests that reducing the cutting age from 80 to 40 years is a feasible strategy to keep SOC content at a suitable level to preserve soil functioning. In contrast, in intermediate and low biomass production forests, reducing the cutting age to 40 years leads to a significant decrease in the SOC levels, making this management unsuitable from a soil ecological perspective. However, according to the results, thinning and tending activities can be applied to South Korean forests regardless of the level of biomass production.

In addition to the assessment of SOC dynamics, it is of high importance to study other ecosystem services linked to soil functioning (e.g., soil functioning indicators, water regulation ability). In this study, we have provided a theoretical framework for such an analysis. The crux is that some ecosystem services could be improved without modifying SOC accumulation directly. Along these lines, we have shown that increasing tree species diversity in forests could reinforce soil functioning and, therefore, other important ecosystem services such as water provision and biomass production. Additionally, this leads to an increase in the resilience of the ecosystem and, thus, makes the forest ecosystem less susceptible to climate impacts. These soil and ecological processes are not directly related to SOC accumulation dynamics, but they are of vital importance to strengthen the resilience of the forest ecosystem. Accordingly, we propose that future studies of the consequences of forest management practices in South Korea and other mid-latitude countries on ecosystem services consider this theoretical framework and SOC assessment as a starting point for future ecosystem services assessments.

Finally, it is important to note that human needs must also be considered. To address forest resilience, while fulfilling economic and social needs, adequate sustainable forest management is needed. In this context, sustainable management can be defined as the use of forests in a way that maintains their ecological functioning to fulfil in the present and future relevant ecological, economic, and social functions and that does not cause damage to other ecosystems [80]. Following this definition, in order to include soil preservation in forest management, to incentivize sustainable management in forests, and to ensure the resilience of the forest ecosystem, financial and policy instruments should be considered. It is important to note that such policy formation is not a static process, but it must be continuously reviewed in an iterative process where the "adaptive management" [81] allows reviewing and modifying decisions and processes and developing options for stakeholders and policymakers, leading management practices to develop as it proceeds [33]. In the following section, we discuss potential approaches. 


\subsection{Lessons for Forest Management Policies}

The analysis shows that guiding policy choice by focusing on particular ecosystem services can be detrimental to forest resilience, societal needs, or both. Maximizing timber production by, for example, subsidizing the timber industry (Scenario B) could lead to a deterioration of water regulation services and resilience to unexpected natural and anthropogenic interventions. Subsidizing timber production would thus need to be complemented with incentives to increase tree species diversity in the process (Scenario C). This could happen through regulation, payments for ecosystem services, or an adjustment of the timber production subsidies.

If, on the other hand, the main policy goal is not to increase timber production, but to maximize the amount of $\mathrm{C}$ stored in the forests and preserve habitat for biodiversity, possible policy approaches could look totally different. For example, protecting forests by making them national parks (Scenario A) could achieve this goal and, at the same time, raise recreational value that could also attract tourists and thus potentially money, which could then be redirected to accompanying management practices like thinning and pruning that could additionally stabilize water regulating services. Going from theory to the case of South Korea, the country has already had considerable reforestation successes, motivated by a range of objectives such as fostering plantations for fuel wood, increasing commercial timber production, and counteracting erosion [39]. However, rapid progress that was mainly led by government and the public has resulted in a mismatch between tree species and the surrounding environment, where improvements in soil physical properties and other parameters have occurred as side effects, but were not explicitly targeted from the beginning [82]. There is thus room for improvement in sustainability and resilience to future challenges such as climate change.

In addition, following the Paris Agreement in 2015 and ongoing emissions at approximately $40 \mathrm{Gt} \mathrm{CO}_{2}$ per year [83], reforestation objectives are changing - $\mathrm{C}$ sequestration is becoming more important in the face of dwindling $C$ budgets [20]. Despite recent reductions in forest area, South Korean forests still absorb $\mathrm{CO}_{2}$ (1.2 times more if not only biomass is considered, but also soils and litter [38]). Reforestation can thus be an effective mitigation strategy, especially in the face of shrinking and limited agricultural lands for SOC sequestration [84]. Many countries that are in the mid-latitude region also have limited agricultural lands for SOC sequestration, but usually also see rural-urban migration and abandoned areas that could be used for reforestation. Therefore, there is room for improvement within South Korea and there are lessons to be learned from the policy approaches to reforestation adopted in other countries. In particular, the example of South Korea demonstrates that strong government commitment and co-design with economic development strategies are key, making it a realistic example also for countries with less economic power. The drivers of success of the South Korean forestation programs have been previously analyzed $[39,82,85,86]$. They are categorized in Table 1.

Table 1. Drivers of success of the South Korean forestation programs (data from $[39,82,85,86])$.

\begin{tabular}{ccc}
\hline Government Commitment & Continued Economic Growth & Economic Incentives \\
\hline $\begin{array}{c}\text { Clear quantifiable goals in the } \\
\text { national reforestation program }\end{array}$ & Fuel switch (from fuel wood to coal) & Provision of seedlings \\
\hline $\begin{array}{c}\text { Strong engagement of all } \\
\text { administrative levels }\end{array}$ & Rural-urban migration (abandoned land) & $\begin{array}{c}\text { Loans to villages to establish } \\
\text { nurseries }\end{array}$ \\
\hline $\begin{array}{c}\text { Education and information, } \\
\text { mobilization of citizens }\end{array}$ & Price guarantees \\
\hline $\begin{array}{c}\text { Laws and regulations (e.g., Forest } \\
\text { Act, Slash-and-Burn Clearance } \\
\text { regulation, enforcement against } \\
\text { illegal logging, prohibition of fuel } \\
\text { wood flow to urban areas) }\end{array}$ & $\begin{array}{c}\text { Support of farmer livelihoods } \\
\text { during Slash-and-Burn } \\
\text { Clearance Project }\end{array}$ \\
\hline $\begin{array}{c}\text { Promotion of inter-agency } \\
\text { cooperation and coordination }\end{array}$ & Results-based rewards and grants \\
\hline
\end{tabular}


In general, incentives that could increase $C$ sequestration include $C$ pricing, regulation (e.g., prescribing tree diversity to forest managers), promotion of best practices, facilitating access to finance, but also avoiding incentives for monocultures, for example. However, climate change presents different stakeholders with different uncertainties: policy uncertainty deters investment and the risk of future disturbances discourages forest owners from reforesting for $\mathrm{C}$ storage when sequestration is likely to be reversed. Financing offers a set of tools to deal with these risks. For example, in the Reduced Emissions from Deforestation and Degradation (REDD+) context, it has been proposed to work with call options [87]. A financial call option represents the right, but not the obligation, to buy a pre-specified amount of a particular commodity or financial instrument at the expiration date for an agreed strike price. The seller must sell the commodity or financial instrument to the buyer. Applied to the reforestation context, the analogy would amount to a long-term contract (e.g., 10-year "warrant") with an upfront payment sufficient to at least cover costs during the contract period. For instance, a buyer would pay $\$ 1$ for the right to buy a $C$ credit from reforestation for $\$ 20$ in 2030 . The verified $C$ sequestration would be held "in reserve" until 2030 and so there would be finances to fund reforestation activities without committing the buyer to exercise the option in 2030. Options could be combined with minimum price guarantees from the public sector to further decrease the risk on the supplier side (for example, a fund would grant the seller the right, but not the obligation, to sell their credit for $\$ 5$ in 2030).

\section{Conclusions}

The South Korean reforestation process has led to a remarkable increase in the amount of $C$ stored in forests, leading to a decrease in the risk of droughts, landslides, and soil erosion. However, the need for timber led the South Korean authorities to implement certain forest management practices aimed at increasing timber extraction, such as reducing the clearcut interval from 80 to 40 years. We conclude that it is only in high biomass production forests that this measure can be implemented without affecting SOC content-and, thus, soil functioning-negatively. Nevertheless, our theoretical framework suggests that it is possible to improve soil functioning and other key ecosystem services (water supply and biomass production) by increasing tree species diversity. Therefore, the negative effects on soils of relatively low biomass production forests when extracting timber could be compensated or palliated by increasing tree species diversity. In this line, future studies should address the quantification of this effect.

However, protecting soils by limiting timber extraction or increasing tree species diversity is costly and subject to uncertainties; therefore, effective incentive structures are needed. South Korea offers a number of lessons learned in reforestation policy and these insights can be combined with new ideas arising, for example, from the REDD+ context, where similar uncertainties apply.

Author Contributions: Conceptualization, J.L.V.-V. and S.F.; Methodology, J.L.V.-V., S.F., C.S., J.L., M.K., W.-K.L. and Y.S.; Software, J.L. and J.L.V.-V.; Validation, J.L.V.-V. and J.L.; Formal Analysis, J.L.V.-V. and S.F.; Investigation, J.L.V.-V. and S.F.; Resources, S.F., W.-K.L. and Y.S.; Data Curation, J.L.V.-V. and J.L.; Writing-Original Draft Preparation, J.L.V.-V., S.F. and C.S.; Writing-Review \& Editing, S.F.; Visualization, J.L.V.-V.; Supervision, S.F., C.S., M.K., W.-K.L. and Y.S.; Project Administration, C.S.; Funding Acquisition, S.F., C.S., W.-K.L. and Y.S.

Funding: This research was part of the "Network for Enhanced Ecosystem Services (NEES, grant number 01DR17002)" project supported by the German Federal Ministry of Education and Research (BMBF) and the Korea National Research Foundation. The project was developed within the frame of the Mid-Latitude Region Network.

Conflicts of Interest: The authors declare no conflict of interest.

\section{References}

1. Costanza, R.; d'Arge, R.; de Groot, R.; Farber, S.; Grasso, M.; Hannon, B.; Naeem, S.; Limburg, K.; Paruelo, J.; O'Neill, R.V.; et al. The value of the world's ecosystem services and natural capital. Nature 1997, 387, $253-260$. [CrossRef] 
2. MEA. Millennium Ecosystem Assessment (MEA): Ecosystems and Human Well-Being: Synthesis; Island Press: Washington, DC, USA, 2005.

3. TEEB. The Economics of Ecosystems and Biodiversity (TEEB): TEEB for Local and Regional Policy Makers; Progress Press: Valletta, Malta, 2010.

4. Winter, S.; Bauer, T.; Strauss, P.; Kratschmer, S.; Paredes, D.; Popescu, D.; Landa, B.; Guzmán, G.; Gómez, J.A.; Guemion, M.; et al. Effects of vegetation management intensity on biodiversity and ecosystem services in vineyards: A meta-analysis. J. Appl. Ecol. 2018, 55, 2484-2495. [CrossRef] [PubMed]

5. Daryanto, S.; Fu, B.; Wang, L.; Jacinthe, P.A.; Zhao, W. Quantitative synthesis on the ecosystem services of cover crops. Earth Sci. Rev. 2018, 185, 357-373. [CrossRef]

6. Torralba, M.; Fagerholm, N.; Burgess, P.J.; Moreno, G.; Plieninger, T. Do European agroforestry systems enhance biodiversity and ecosystem services? A meta-analysis. Agric. Ecosyst. Environ. 2016, 230, 150-161. [CrossRef]

7. Ojea, E.; Loureiro, M.; Barrio, M. Ecosystem Services and REDD: Estimating the Benefits of Non-Carbon Services in Worldwide Forests. World Dev. 2016, 78, 246-261. [CrossRef]

8. Setten, G.; Brown, K.M. Ecosystem services as an integrative framework: What is the potential? Land Use Policy 2018, 75, 549-556. [CrossRef]

9. Sotirov, M.; Sallnäs, O.; Eriksson, L.O. Forest owner behavioral models, policy changes, and forest management. An agent-based framework for studying the provision of forest ecosystem goods and services at the landscape level. For. Policy Econ. 2017, 103, 79-89. [CrossRef]

10. Wang, T.; He, G.S.; Zhou, Q.L.; Gao, J.Z.; Deng, L.J. Designing a framework for marine ecosystem assets accounting. Ocean Coast. Manag. 2018, 163, 92-100. [CrossRef]

11. Dominati, E.J.; Patterson, M.G.; Mackay, A.D. A framework for classifying and quantifying the natural capital and ecosystem services of soils. Ecol. Econ. 2010, 69, 1858-1868. [CrossRef]

12. Bennet, E.M.; Peterson, G.D.; Gordon, L.J. Understanding relationships among multiple ecosystem services. Ecol. Lett. 2009, 12, 1394-1404. [CrossRef]

13. Gaiser, T.; Stahr, K. Soil organic carbon, soil formation and soil fertility. In Ecosystem Services and Carbon Sequestration in the Biosphere; Lal, R., Lorenz, K., Hüttl, R.F., Schneider, B.U., Braun, J., Eds.; Springer: Dordrecht, The Netherlands, 2013; pp. 407-417.

14. Jónsson, J.O.G.; Davíðsdóttir, B. Classification and valuation of soil ecosystem services. Agric. Syst. 2016, 145, 24-38. [CrossRef]

15. Lal, R. Societal value of soil carbon. J. Soil Water Conserv. 2014, 69, 186-192. [CrossRef]

16. Adhikari, K.; Hartemink, A.E. Linking soils to ecosystem services-A global review. Geoderma 2016, 262, 101-111. [CrossRef]

17. Smith, P. Soil carbon sequestration and biochar as negative emission technologies. Glob. Chang. Biol. 2016, 22, 1315-1324. [CrossRef] [PubMed]

18. Fuss, S.; Lamb, W.F.; Callaghan, M.W.; Hilaire, J.; Creutzig, F.; Amann, T.; Beringer, T.; de Oliveira Garcia, W.; Hartmann, J.; Khanna, T.; et al. Negative emissions-Part 2: Costs, potentials and side effects. Environ. Res. Lett. 2018, 13, 063002. [CrossRef]

19. Minx, J.C.; Lamb, W.F.; Callaghan, M.W.; Fuss, S.; Hilaire, J.; Creutzig, F.; Amann, T.; Beringer, T.; de Oliveira Garcia, W.; Hartmann, J.; et al. Negative emissions-Part 1: Research landscape and synthesis. Environ. Res. Lett. 2018, 13, 062001. [CrossRef]

20. Intergovernmental Panel on Climate Change (IPCC). Summary for policymakers. In Global Warming of $1.5^{\circ} \mathrm{C}$. An IPCC Special Report on the Impacts of Global Warming of $1.5^{\circ} \mathrm{C}$ above Pre-Industrial Levels and Related Global Greenhouse Gas Emission Pathways, in the Context of Strengthening the Global Response to the Threat of Climate Change, Sustainable Development, and Efforts to Eradicate Poverty; WMO: Geneva, Switzerland, 2018.

21. Smith, P. Carbon sequestration in croplands: The potential in Europe and the global context. Eur. J. Agron. 2004, 20, 229-236. [CrossRef]

22. Aguilera, E.; Lassaletta, L.; Gattingerd, A.; Gimenoe, B. Managing soil carbon for climate change mitigation and adaptation in Mediterranean cropping systems: A meta-analysis. Agric. Ecosyst. Environ. 2013, 168, 25-36. [CrossRef]

23. Poeplau, C.; Don, A. Carbon sequestration in agricultural soils via cultivation of cover crops-A meta-analysis. Agric. Ecosyst. Environ. 2015, 200, 33-41. [CrossRef] 
24. Zhao, X.; Zhang, R.; Xue, J.F.; Pu, C.; Zhang, X.Q.; Liu, S.L.; Chen, F.; Lal, R.; Zhang, H.L. Management-induced changes to soil organic carbon in China: A meta-analysis. Adv. Agron. 2015, 134, 1-50.

25. Vicente-Vicente, J.L.; García-Ruiz, R.; Francaviglia, R.; Aguilera, E.; Smith, P. Soil carbon sequestration rates under Mediterranean woody crops using recommended management practices: A meta-analysis. Agric. Ecosyst. Environ. 2016, 235, 204-214. [CrossRef]

26. Dignac, M.-F.; Derrien, D.; Barré, P.; Barot, S.; Cécillon, L.; Chenu, C.; Chevallier, T.; Freschet, G.T.; Garnier, P.; Guenet, B.; et al. Increasing soil carbon storage: Mechanisms, effects of agricultural practices and proxies. A review. Agron. Sustain. Dev. 2017, 37, 14. [CrossRef]

27. Francaviglia, R.; Di Bene, C.; Farina, R.; Salvati, L.; Vicente-Vicente, J.L. Assessing “4 per 1000" soil organic carbon storage rates under Mediterranean climate: A comprehensive data analysis. Mitig. Adapt. Strateg. Glob. Chang. 2019, 24,1-24. [CrossRef]

28. Francaviglia, R.; Ledda, L.; Farina, R. Organic carbon and ecosystem services in agricultural soils of the Mediterranean Basin. In Sustainable Agriculture Reviews 28; Gaba, S., Smith, B., Lichtfouse, E., Eds.; Springer International Publishing: Cham, Switzerland, 2018; pp. 183-210.

29. Lal, R.; Lorenz, K.; Hüttl, R.F.; Schneider, B.U.; Braun, J. Ecosystem Services and Carbon Sequestration in the Biosphere; Springer: Dordrecht, The Netherlands, 2013.

30. Andrea, F.; Binib, C.; Amaduccia, S. Soil and ecosystem services: Current knowledge and evidences from Italian case studies. Appl. Soil Ecol. 2018, 123, 693-698. [CrossRef]

31. Griscom, B.W.; Adams, J.; Ellis, P.W.; Houghton, R.A.; Lomax, G.; Miteva, D.A.; Schlesinger, W.H.; Shoch, D.; Siikamäki, J.V.; Smith, P.; et al. Natural climate solutions. Proc. Natl. Acad. Sci. USA 2017, 114, 11645-11650. [CrossRef]

32. Denman, K.; Brasseur, G.; Chidthaisong, A.; Ciais, P.; Cox, P.; Dickinson, R.; Hauglustaine, D.; Heinze, C.; Holland, E.; Jacob, D.; et al. Couplings between changes in the climate system and biogeochemistry. In Climate Change 2007: The Physical Science Basis. Contribution of Working Group I to the Fourth Assessment Report of the Intergovernmental Panel on Climate Change; Solomon, S., Qin, D., Manning, M., Chen, Z., Marquis, M., Averyt, K., Tignor, M., Miller, H., Eds.; Cambridge University Press: Cambridge, UK; New York, NY, USA, 2007; pp. 500-587.

33. Jandl, R.; Schüler, S.; Schindlbacher, A.; Tomiczek, C. Forests, carbon pool, and timber production. In Ecosystem Services and Carbon Sequestration in the Biosphere; Lal, R., Lorenz, K., Hüttl, R.F., Schneider, B.U., Braun, J., Eds.; Springer: Dordrecht, The Netherlands, 2013; pp. 101-130.

34. Kuzyakov, Y.; Domanski, G. Carbon input by plants into the soil. Review. J. Soil Sci. Plant Nutr. 2000, 163, 421-431. [CrossRef]

35. Ludwig, B.; Schulz, E.; Merbach, I.; Rethemeyer, J.; Flessa, H. Predictive modelling of the C dynamics for eight variants of the long-term static fertilization experiment in Bad Lauchstädt using the Rothamsted Carbon Model. Eur. J. Soil Sci. 2007, 58, 1155-1163. [CrossRef]

36. Nannipieri, P.; Ascher, J.; Ceccherini, M.T.; Guerri, G.; Renella, G.; Pietramellara, G. Recent Advances in Functional Genomics and Proteomics of Plant Associated Microbes. In Molecular Mechanisms of Plant and Microbe Coexistence Soil Biology; Nautiyal, C.S., Dion, P., Eds.; Springer: Berlin/Heidelberg, Germany, 2008; Volume 15, pp. 215-241.

37. Kuzyakov, Y.; Friedel, J.; Stahr, K. Review of mechanisms and quantification of primig effects. Soil Biol. Biochem. 2000, 32, 1485-1498. [CrossRef]

38. Lee, J.; Lim, C.H.; Kim, G.S.; Markandya, A.; Chowdhury, S.; Kim, S.J.; Lee, W.K.; Son, Y. Economic viability of the national-scale forestation program: The case of success in the Republic of Korea. Ecosyst. Serv. 2018, 29, 40-46. [CrossRef]

39. Bae, J.S.; Joo, R.W.; Kim, Y.S. Forest transition in South Korea: Reality, path and drivers. Land Use Policy 2012, 29, 198-207. [CrossRef]

40. Korea Forest Service (KFS). Statistical Yearbook of Forestry; Korea Forest Service: Deajeon, Korea, 2016.

41. Choi, S.D.; Chang, Y.S. Factors affecting the distribution of the rate of carbon uptake by forests in South Korea. Environ. Sci. Technol. 2004, 38, 484-488. [CrossRef]

42. Li, X.; Yi, M.J.; Son, Y.; Jin, G.; Han, S.S. Forest biomass carbon accumulation in Korea from 1954 to 2007. Scand. J. For. Res. 2010, 25, 554-563. [CrossRef] 
43. Fang, J.; Guo, Z.; Hu, H.; Kato, T.; Muraoka, H.; Son, Y. Forest biomass carbon sinks in East Asia, with special reference to the relative contributions of forest expansion and forest growth. Glob. Chang. Biol. 2014, 20, 2019-2030. [CrossRef]

44. Piao, S.L.; Ito, A.; Li, S.G.; Huang, Y.; Ciais, P.; Wang, X.H.; Peng, S.S.; Nan, H.J.; Zhao, C.; Ahlström, A.; et al. The carbon budget of terrestrial ecosystems in East Asia over the last two decades. Biogeosciences 2012, 9 , 3571-3586. [CrossRef]

45. Yoo, S.; Kwak, D.A.; Cui, G.; Lee, W.K.; Kwak, H.; Ito, A.; Son, Y.; Jeon, S. Estimation of the ecosystem carbon budget in South Korea between 1999 and 2008. Ecol. Res. 2013, 28, 1045-1059. [CrossRef]

46. Lee, J.; Yoon, T.K.; Han, S.; Kim, S.; Yi, M.J.; Park, G.S.; Kim, C.; Son, Y.M.; Kim, R.; Son, Y. Estimating the carbon dynamics of South Korean forests from 1954 to 2012. Biogeosciences 2014, 11, 4637. [CrossRef]

47. Lee, J.; Tolunay, D.; Makineci, E.; Çömez, A.; Son, Y.M.; Kim, R.; Son, Y. Estimating the age-dependent changes in carbon stocks of Scots pine (Pinus sylvestris L.) stands in Turkey. Ann. For. Sci. 2016, 73, 523-531. [CrossRef]

48. Kim, M. Impacts Assessment of Climate Change and Management Strategies on Carbon, Water, and Wood Products in Korean Forests. Ph.D. Thesis, Korea University, Seoul, Korea, 2018. Available online: http://dcollection.korea.ac.kr/jsp/common/DcLoOrgPer.jsp?sItemId=000000080712 (accessed on 20 July 2018).

49. Piao, D.; Kim, M.; Choi, G.M.; Moon, J.; Yu, H.; Lee, W.K.; Wang, S.W.; Jeon, S.W.; Son, Y.; Son, Y.M.; et al. Development of an Integrated DBH Estimation Model Based on Stand and Climatic Conditions. Forests 2018, 9, 155. [CrossRef]

50. Kim, M.; Lee, W.; Kurz, W.; Kwak, D.; Morken, S.; Smyth, C.; Ryu, D. Estimating carbon dynamics in forest carbon pools under IPCC standards in South Korea using CBM-CFS3. iForest 2017, 10, 83-92. [CrossRef]

51. Prada, M.; Bravo, F.; Berdasco, L.; Canga, E.; Martínez-Alonso, C. Carbon sequestration for different management alternatives in sweet chestnut coppice in northern Spain. J. Clean. Prod. 2016, 135, 1161-1169. [CrossRef]

52. Tallis, H.; Kareiva, P. Ecosystem services. Curr. Biol. 2005, 15, 746-748. [CrossRef] [PubMed]

53. Carpenter, S.R.; Mooney, H.A.; Agard, J.; Capistrano, D.; Defries, R.S.; Diaz, S.; Dietz, T.; Duraiappah, A.K.; Oteng-Yeboah, A.; Pereira, H.M.; et al. Science for managing ecosystem services: Beyond the millennium ecosystem assessment. Proc. Natl. Acad. Sci. USA 2009, 106, 1305-1312. [CrossRef] [PubMed]

54. Wiesmeier, M.; Urbanski, U.; Hobley, E.; Lang, B.; von Lützow, M.; Marin-Spiotta, E.; Van Wesemael, B.; Rabot, E.; Ließ, M.; García-Franco, N.; et al. Soil organic carbon storage as a key function of soils-A review of drivers and indicators at various scales. Geoderma 2019, 333, 149-162. [CrossRef]

55. Scheffer, M.; Carpenter, S.R. Catastrophic regime shifts in ecosystems: Linking theory to observation. Trends Ecol. Evol. 2003, 18, 648-656. [CrossRef]

56. Bennett, E.M.; Cumming, G.; Peterson, G.D. A Systems Model Approach to Determining Resilience Surrogates for Case Studies. Ecosystems 2005, 8, 945-957. [CrossRef]

57. Nguyen, C. Rhizodeposition of organic C by plants: Mechanisms and controls. Agronomy 2003, 23, 375-396. [CrossRef]

58. Haichar, F.Z.; Santaella, C.; Heulin, T.; Achouak, W. Root exudates mediated interactions belowground. Soil Biol. Biochem. 2014, 77, 69-80. [CrossRef]

59. Wardle, D.A. A comparative-assessment of factors which influence microbial biomass carbon and nitrogen levels in soil. Biol. Rev. Camb. Philos. Soc. 1992, 67, 321-358. [CrossRef]

60. Anderson, J.P.E.; Domsch, K.H. Quantities of plant nutrients in the microbial biomass of selected soils. Soil Sci. 1980, 130, 211-216. [CrossRef]

61. de Andrade Bonetti, J.; Anghinoni, I.; de Moraes, M.T.; Fink, J.R. Resilience of soils with different texture, mineralogy and organic matter under long-term conservation systems. Soil Tillage Res. 2017, 174, 104-112. [CrossRef]

62. Feger, K.H.; Hawtree, D. Soil carbon and water security. In Ecosystem Services and Carbon Sequestration in the Biosphere; Lal, R., Lorenz, K., Hüttl, R.F., Schneider, B.U., Braun, J., Eds.; Springer: Dordrecht, The Netherlands, 2013; pp. 79-99.

63. Ilstedt, U.; Tobella, A.B.; Bazié, H.R.; Bayala, J.; Verbeeten, E.; Nyberg, G.; Sanou, J.; Benegas, L.; Murdiyarso, D.; Ludon, H.; et al. Intermediate tree cover can maximize groundwater recharge in the seasonally dry tropics. Sci. Rep. 2016, 6, 21930. [CrossRef] [PubMed] 
64. Kim, G.; Lim, C.H.; Kim, S.; Lee, J.; Son, Y.; Lee, W.K. Effect of national-scale afforestation on forest water supply and soil loss in South Korea, 1971-2010. Sustainability 2017, 9, 1017. [CrossRef]

65. UN Development Programme. Sustainable Development Goals. Policy Brief Series NO.1. Valuation of Reforestation in Terms of Disaster Risk Reduction: A Technical Study from the Republic of Korea; UNDP: Seoul, Korea, 2017. Available online: http://www.undp.org/content/dam/uspc/docs/USPC\%20Policy\%20Brief\%20No.1.pdf (accessed on 15 June 2018).

66. Kim, M.; Lee, W.K.; Son, Y.; Yoo, S.; Choi, G.M.; Chung, D.J. Assessing the impacts of topographic and climatic factors on radial growth of major forest forming tree species of South Korea. For. Ecol. Manag. 2017, 404, 269-279. [CrossRef]

67. Ryan, M.G.; Binkley, D.; Fownes, J.H. Age-related decline in forest productivity: Pattern and process. Adv. Ecol. Res. 1997, 27, 213-262.

68. Scheffer, M.; Carpenter, S.R.; Foley, J.; Folke, C.; Walker, B.H. Catastrophic shifts in ecosystems. Nature 2001, 413, 591-596. [CrossRef] [PubMed]

69. Gamefeldt, L.; Hillebrand, H.; Jonsson, P.R. Multiple functions increase the importance of biodiversity for overall ecosystem functioning. Ecology 2008, 89, 1223-1231. [CrossRef]

70. Mace, G.M.; Norris, K.; Fitter, A.H. Biodiversity and ecosystem services: A multi-layered relationship. Trends Ecol. Evol. 2012, 27, 24-31. [CrossRef] [PubMed]

71. Marschner, P.; Neumann, G.; Kania, A.; Weisskopf, L.; Lieberei, R. Spatial and temporal dynamics of bacterial community composition in the rhizosphere of cluster roots of white lupin (Lupinus albus L.). Plant Soil 2002, 246, 167-174. [CrossRef]

72. Gomes, N.C.M. Dynamics of fungal communities in bulk and maize rizosphere soil in the tropics. Appl. Environ. Microbiol. 2003, 69, 3758-3766. [CrossRef] [PubMed]

73. Nicol, G.W.; Glover, L.A.; Prosser, J.I. Spatial analysis of archaeal community structure in grassland soil. Appl. Environ. Microbiol. 2003, 69, 7420-7429. [CrossRef] [PubMed]

74. González-Sánchez, E.J.; Mkomwa, S.; Conway, G.; Kassam, A.; Ordóñez-Fernández, R.; Moreno-García, M.; Repullo-Ruibériz de Torres, M.; Gil-Ribes, J.A.; Basch, G.; Veroz-González, O.; et al. Making Climate Change Mitigation and Adaptability Real in Africa with Conservation Agriculture. 2018. Available online: https://dspace.uevora.pt/rdpc/bitstream/10174/23936/1/Conservation_Agriculture_Climate_Change_ Africa\%281\%29.pdf (accessed on 5 November 2018).

75. Mayer, H. Waldbau auf Soziologisch-Ökologischer Grundlage. G.; Fischer: Stuttgart, Germany, 1984.

76. Oliver, C.D.; Larsen, B.C. Forest Stand Dynamics; McGraw-Hill Inc.: New York, NY, USA, 1990.

77. Puettmann, K.J.; Coates, K.D.; Messier, C. A Critique of Silviculture-Managing for Complexity; Island Press: Washington, DC, USA, 2009.

78. Loureau, M.; Naeem, S.; Inchausti, P. Biodiversity and Ecosystem Functioning: Synthesis and Perspectives; Oxford University Press: Oxford, UK, 2002.

79. De Deyn, G.B. Ecosystem carbon and soil biodiversity. In Ecosystem Services and Carbon Sequestration in the Biosphere; Lal, R., Lorenz, K., Hüttl, R.F., Schneider, B.U., Braun, J., Eds.; Springer: Dordrecht, The Netherlands, 2013; pp. 131-153.

80. Ministerial Conference on the Protection of Forests in Europe (MCPFE). Improved Pan-European Indicators for Sustainable Forest Management. 2003. Available online: https://www.foresteurope.org/documentos/ improved_indicators.pdf (accessed on 15 March 2019).

81. Holling, C.B. Adaptive Environmental Assessment and Management; John Wiley \& Sons: London, UK, 1978.

82. Convention on Biological Diversity (CBD). Lessons Learned from the Republic of Korea's National Reforestation Programme, 2014. 2015. Available online: https://www.cbd.int/ecorestoration/doc/KoreanStudy_Final-Version-20150106.pdf (accessed on 20 March 2019).

83. UN Environment. Emissions Gap Report. 2018. Available online: http://wedocs.unep.org/bitstream/handle/ 20.500.11822/26895/EGR2018_FullReport_EN.pdf?sequence=1\&isAllowed=y (accessed on 15 January 2019).

84. Minasny, B.; Malone, B.P.; McBratney, A.B.; Angers, D.A.; Arrouays, D.; Chambers, A.; Chaplot, V.; Chen, Z.-S.; Cheng, K.; Das, B.S.; et al. Soil carbon 4 per mille. Geoderma 2017, 292, 59-86. [CrossRef]

85. Lee, K.B.; Bae, J.S. Factors of success of the clearance policy for slash-and-burn fields in the 1970s. J. Korean For. Soc. 2007, 96, 325-337. 
86. Bae, J.S.; Lee, K.B. Impacts of the substitution of firewood for home use on the forest greening after the 1945 Liberation of Korea. J. Korean For. Soc. 2006, 95, 60-72.

87. Golub, A.; Lubowski, R.; Piris-Cabezas, P. Balancing Risks from Climate Policy Uncertainties: The Role of Options and Reduced Emissions from Deforestation and Forest Degradation. Ecol. Econ. 2017, 138, 90-98. [CrossRef] 